\title{
Phenethyl Isothiocyanate (PEITC) and Benzyl Isothiocyanate (BITC) Inhibit Human Melanoma A375.S2 Cell Migration and Invasion by Affecting MAPK Signaling Pathway In Vitro
}

\author{
YI-SHIH MA ${ }^{1,2}$, YUNG-TING HSIAO ${ }^{3}$, JEN-JYH LIN ${ }^{4}$, CHING-LUNG LIAO ${ }^{5}$, \\ CHIN-CHUNG LIN ${ }^{6,7 *}$ and JING-GUNG CHUNG ${ }^{3,8^{*}}$ \\ ${ }^{1}$ School of Chinese Medicine for Post-Baccalaureate, I-Shou University, Kaohsiung, Taiwan, R.O.C.; \\ ${ }^{2}$ Department of Chinese Medicine, E-Da Hospital, Kaohsiung, Taiwan, R.O.C.; \\ ${ }^{3}$ Department of Biological Science and Technology, China Medical University, Taichung, Taiwan, R.O.C.; \\ ${ }^{4}$ Division of Cardiology, China Medical University Hospital, Taichung, Taiwan, R.O.C.; \\ ${ }^{5}$ Graduate Institute of Chinese Medicine, China Medical University, Taichung, Taiwan, R.O.C.; \\ ${ }^{6}$ Departments of Chinese Medicine, Feng-Yuan Hospital, Ministry of Health and Welfare, \\ Executive Yuan, Taichung, Taiwan, R.O.C.; \\ ${ }^{7}$ General Education Center, Central Taiwan University of Science and Technology, Taichung, Taiwan, R.O.C.; \\ ${ }^{8}$ Department of Biotechnology, Asia University, Taichung, Taiwan, R.O.C.
}

\begin{abstract}
Background/Aim: Numerous evidence has shown that PEITC and BITC inhibit cancer cell migration and invasion. In this study, we investigated the anti-metastatic mechanisms of PEITC and BITC in human melanoma cancer A375.S2 cells in vitro. Materials and Methods: We used a cell viability assay, an in-vitro scratch wound healing assay, a transwell assay for cell migration and invasion, a gelatin zymography assay, western blotting and EMSA to examine the anti-metastatic mechanisms of PEITC and BITC in A375.S2 cells. Results: Sublethal concentrations of PEITC $(0,1,2$ and $2.5 \mu \mathrm{M})$ and BITC $(0,0.5,1$ and $2 \mu \mathrm{M})$ inhibited mobility, migration and invasion of A375.S2 cells that were assayed by wound healing and Transwell filter. PEITC and BITC inhibited MMP-2 activity in A375.S2 cells, as assessed
\end{abstract}

This article is freely accessible online.

\footnotetext{
*These Authors contributed equally to this work.

Correspondence to: Professor Jing-Gung Chung, Department of Biological Science and Technology, China Medical University, No 91, Hsueh-Shih Road, Taichung, Taiwan, R.O.C. Tel: +886 422053366, ext. 8000, Fax: +886 422053764, e-mail: jgchung@mail.cmu.edu.tw; Dr. Chin-Chung Lin, Departments of Chinese Medicine, Feng-Yuan Hospital, Ministry of Health and Welfare, Executive Yuan, Taichung, Taiwan. NO.100, An-Kan Road, Fengyuan District, Taichung, Taiwan, R.O.C. Tel: +886 425271180, ext. 2656, Fax: +886 425284445, email: lcc988@ms16.hinet.net
}

Key Words: PEITC, BITC, migration, invasion, NF-кB, MMP-2. by gelatin zymography assay. Results from western blotting indicated that PEITC (2.5 $\mu M)$ and BITC (2 $\mu M)$ decreased the levels of p-p38 following 24 and $48 \mathrm{~h}$ treatment. PEITC (1-2.5 $\mu M)$ reduced the levels of $p-J N K 1 / 2$ proteins following 48-h treatment but BITC increased p-JNK1/2 levels following 24-h treatment. PEITC $(2.5 \mu M)$ reduced the levels of $p$ ERK1/2 proteins following 48-h treatment but BITC (0.5-2 $\mu M)$ increased $p$-ERK1/2 levels following 24- and 48-h treatment. PEITC and BITC affect cell migration and invasion of A375.S2 cells via MAPK pathway. PEITC and $B I T C$ inhibited MMP-2 activity. PEITC increased $N F-\kappa B$ expression but BITC decreased $N F-k B$ expression in the nucleus. Furthermore, $N F-k B$ p65 binding to DNA was decreased following $2.5 \mu M$ PEITC treatment, but increased following treatment with 1-2 $\mu M$. However, 0.5-2 $\mu M$ BITC treatment decreased the binding of $N F-k B$ to DNA in A375.S2 cells, as assessed by electrophoretic mobility shift (EMSA) assay. Conclusion: Based on these observations, we suggest that PEITC and BITC can be used as antimetastastic agents of human melanoma cells in the future.

Skin cancer is one of the most common malignant neoplasms in the white population. Melanoma is much more common in whites than in other ethnic groups (1). In USA, the incidence of melanoma is the fifth and seventh most common cancer among men and women, respectively (2). Worldwide, the incidence rate of melanoma skin cancer is increasing (3). At ages over the age of 75 years old, the incidence rate is almost three times higher in males than that in females $(4,5)$. In the past years, metastatic melanomas have been increased and led to a high rate of death 
for patients with melanoma (6). The treatment of melanoma includes surgical resection, chemotherapy in non-resectable cases, and immunotherapy; however, the cure rate is still unsatisfying. Therefore, there is urgent need to find and identify new chemicals from natural products for melanoma treatment.

PEITC and BITC both are members of isothiocyanates (ITCs), and have been reported to induce cell death through the induction of cell apoptosis in many human cancer cell lines such as cervical cancer cells (7), non-small cell lung cancer cells (8), prostate cancer cells (9), bladder carcinoma cells (10), breast cancer cells (11), pancreatic carcinoma cells (12) melanoma A375.S2 cells (13).

In human prostate cancer cells, PEITC suppressed the nuclear factor-kB (NF-kB)-regulated gene expression (14) and activated the Atg5-mediated autophagy (15). Recently, we found that PEITC alters gene expression and cell cycle associated protein expression in human glioblastoma GBM 8401 cells (16). We also found that BITC affected cell cycle associated gene expression and apoptosis in human glioblastoma GBM 8401 cells (17). PEITC has been clinically assessed against human lung cancer (18). BITCinduced cell death, involves the induction of ROS production, autophagy and apoptosis in human prostate cancer cells (19). Our previous studies also showed that PEITC and BITC inhibited migration and invasion of human colon cancer HT29 cells through NF-kB and inhibition of MMP-2, -7 and $-9(20,21)$. They also have been found to inhibit migration and invasion of human brain glioblastoma GBM 8401 through the inhibition of uPA, Rho A, and Ras as well as inhibition of MMP-2, -7 and -9 gene expression (22). BITC inhibited the gene expression of MMP-2, -7 and -9, FAK, ROCK1 and Rho A in AGS cells (23). BITC inhibited hepatocellular carcinoma cell migration and invasion via decreasing MMP-2 and -9, survivin and CXCR4 expression (24). Although numerous studies have shown that PEITC and BITC inhibit cancer cell migration and invasion, there is no study on the effect of PEITC and BITC on migration and invasion of human melanoma A375.S2 cells. Herein, we focused on the effects of PEITC and BITC on A375.S2 cell metastasis in vitro and we found that PEITC and BITC suppressed the migration and invasion of A375.S2 cells.

\section{Materials and Methods}

Test chemicals, reagents and culture medium. Phenethyl isothiocyanate (PEITC), benzyl isothiocyanate (BITC), Tris- $\mathrm{HCl}$, Trypsin, Trypan blue, dimethyl sulfoxide (DMSO) and propidium iodide (PI) were purchased from Sigma Chemical Co. (St. Louis, Missouri, USA). Minimum essential medium (MEM) medium, fetal bovine serum (FBS) and penicillin-streptomycin were purchased from Invitrogen (Carlsbad, CA, USA). PEITC and BITC were dissolved in DMSO.

Cell line and culture. Human melanoma A375.S2 cell line was purchased from the Food Industry Research and Development
Institute (Hsinchu, Taiwan) and were cultured in MEM medium supplemented with $10 \%$ fetal bovine serum (FBS), $1 \%$ antibiotics (100 U/ml penicillin and $100 \mu \mathrm{g} / \mathrm{ml}$ streptomycin) and $2 \mathrm{mM} \mathrm{L}-$ glutamine at $37^{\circ} \mathrm{C}$ in a $5 \% \mathrm{CO}_{2}$ humidified atmosphere $(25,26)$.

Cell viability assay. A375.S2 cells were plated at a density of $1 \times 10^{5}$ cells/well in 12 well plate, with MEM overnight and were treated with PEITC or BITC in triplicate with the final concentrations $(0$, $1,1.5,2,2.5$ and $5 \mu \mathrm{M})$ and $(0,0.5,1,2,4$ and $8 \mu \mathrm{M})$ for $48 \mathrm{~h}$, respectively. At the end of incubation, cells were harvested, washed with PBS and were stained with PI $(5 \mu \mathrm{g} / \mathrm{ml})$. The total percentage of cell viability were quantitated by using flow cytometry (BectonDickinson, San Jose, CA, USA) as described previously (22).

In vitro scratch wound healing assay. A375.S2 cells $\left(2 \times 10^{5}\right.$ cells/well) were seeded into 6 well plate for $24 \mathrm{~h}$ and grown until reaching a confluent monolayer, after that media was replaced with serum-free MEM medium. Plates were extensively washed with PBS and then were scratched using a sterile $200 \mu \mathrm{l}$ pipette tip and washed with PBS to remove cell debris. Cells in each well were incubated with PEITC $(0,1,2$ and $2.5 \mu \mathrm{M})$ and BITC $(0,0.5,1$ and $2 \mu \mathrm{M})$ at $37^{\circ} \mathrm{C}$ in a $5 \% \mathrm{CO}_{2}$ humidified atmosphere for 0 or $24 \mathrm{~h}$ and photographed under phase contrast microscopy. Scratch experiments were repeated thrice and representative pictures are presented in this study (27).

Transwell assay for cell migration and invasion examinations. The examination of cell migration and invasion in vitro were performed by using Cell Migration and Invasion System as described previously $(28,29)$. To assay cell migration, A375.S 2 cells $\left(5 \times 10^{4}\right.$ cells/well $)$ were cultured in serum-free MEM and placed in the upper chamber ( $8 \mathrm{~mm}$ pore size; Millipore, Temecula, CA, USA) coated with collagen. MEM with $10 \%$ FBS was placed in the lower chamber. The cells were then incubated with PEITC $(0,1,2$ and $2.5 \mu \mathrm{M})$ and BITC $(0,0.5,1$ and $2 \mu \mathrm{M})$. Cells penetrated the filter to the lower surface (invasive cells) were fixed with $4 \%$ formaldehyde in PBS followed by $2 \%$ crystal violet for staining and all samples were examined and photographed under light microscopy at x200. We counted total cells and measured percentage of inhibition based on cell numbers in each picture. To assay for cell invasion, applied the same protocol with the exception of the use of matrigel instead of collagen on the filter membrane as described previously $(25,30)$.

Gelatin zymography assay. A375.S2 cells $\left(5 \times 10^{5}\right.$ cells/well $)$ were seeded into 6-well plate for $24 \mathrm{~h}$ at $80 \%$ confluency and serum-free MEM medium containing PEITC or BITC was individually added to each plate for 24 or $48 \mathrm{~h}$. At the end of incubation, the conditioned medium was harvested and sample underwent electrophoresis on $8 \%$ SDS-PAGE gel containing $0.2 \%$ gelatin, and then soaked the gel in 2.5\% Triton X-100 in $\mathrm{dH}_{2} \mathrm{O}$ for 30 min two times at room temp. Gels were soaked in substrate buffer $(50 \mathrm{mM}$ Tris $\mathrm{HCl}, 5 \mathrm{mM} \mathrm{CaCl}_{2}, 0.02 \% \mathrm{NaN}_{3}$ and $1 \%$ triton $\mathrm{X}-100, \mathrm{pH} 8.0$ ) at $37^{\circ} \mathrm{C}$ for $24 \mathrm{~h}$ by shaking, stained with $0.2 \%$ Coomassie blue (Bio-Rad, Hercules, CA, USA) in 10\% acetic acid and $50 \%$ methanol and then photographed as described previously (31).

Western blotting analysis. A375.S2 cells were maintained in $10 \mathrm{~cm}$ dish at the density of $1.5 \times 10^{6}$ cells and were incubated with PEITC $(0,1,2$ and $2.5 \mu \mathrm{M})$ or BITC $(0,0.5,1$ and $2 \mu \mathrm{M})$ for 24 or $48 \mathrm{~h}$. At the end of treatment, cells were collected and the whole-cell 

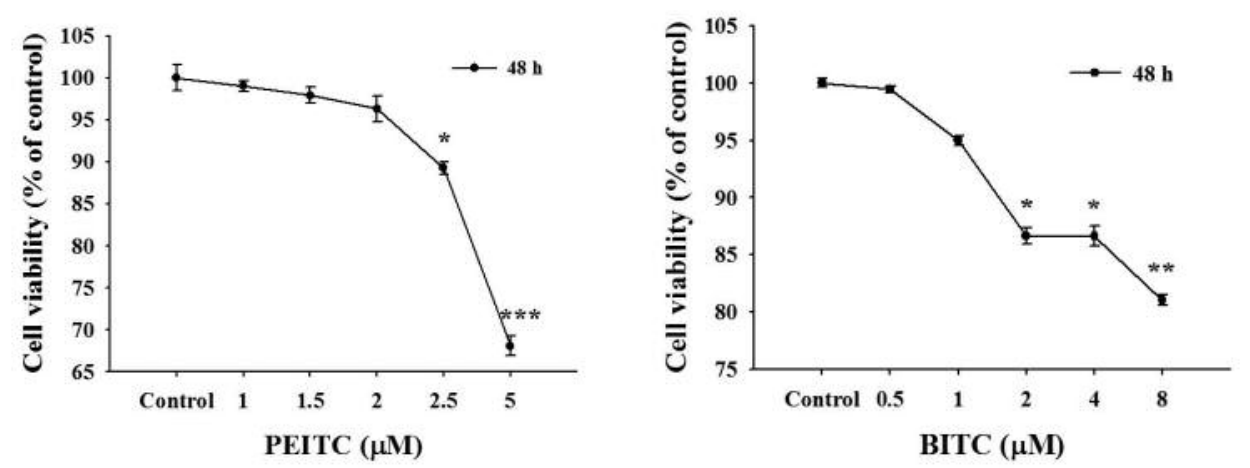

Figure 1. PEITC and BITC affect the cell viability of A375.S2 cells. Cells $\left(1 \times 10^{5}\right.$ cells/well $)$ were incubated with various concentrations of PEITC $(0,1,1.5,2,2.5$ and $5 \mu \mathrm{M})$ and BITC $(0,0.5,1,2,4$ and $8 \mu \mathrm{M})$ for $48 \mathrm{~h}$. Cells were collected for total percentage of total viable cells, as described in Materials and Methods. ${ }^{*} p<0.05, * * p<0.01$ and $*^{* *} p<0.001$, significant difference between PEITC-or BITC-treated groups and the control as analyzed by the Student's t-test.

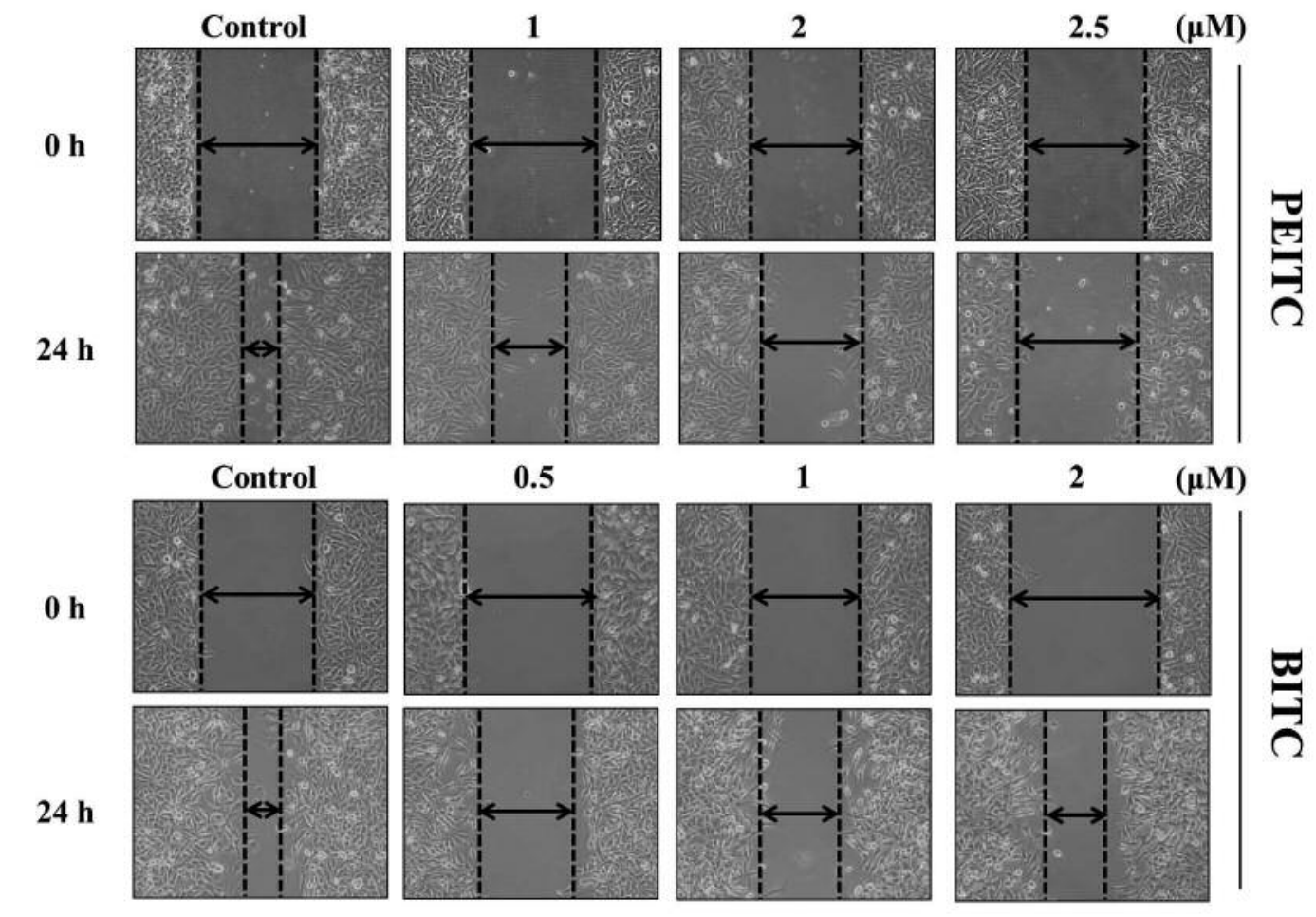

Figure 2. PEITC and BITC affect in vitro wound closure of A375.S2 cells. Cells $\left(2 \times 10^{5}\right.$ cells/well) were maintained in 6-well plates for 24 h and were wounded with a scratch and incubated with PEITC $(0,1,2$ and $2.5 \mu M)$ or BITC $(0,0.5,1$ and $2 \mu M)$ for 24 h. The relative wound closures were photographed using phase contrast microscopy, as described in Materials and Methods.

lysates were subjected to Western blot analysis using antip-ERK1/2, p-p38, p-JNK1/2, PKC, PI3K, p-AKT(Thr308), p-AKT(Ser473), PCNA, p65, TIMP-1, MMP-2, MMP-9, 14-3-3- $\sigma$, GRB2, Ras, SOS-1, N-cadherin, E-cadherin, p-FAK, Lamin A/C and $\beta$-actin. Following washing the membrane was incubated with diluted secondary antibodies (diluted 1: 5,000; Santa Cruz
Biotechnology, Santa Cruz, CA) for $1 \mathrm{~h}$ at room temperature. After the final washing, signals were revealed by enhanced chemiluminescence using the ECL detection system (Amersham $\mathrm{ECL}^{\mathrm{TM}}$; GE Healthcare, Chicago, IL, USA) and recorded on film. The relative photographic density was quantitated as described previously (32). 
A

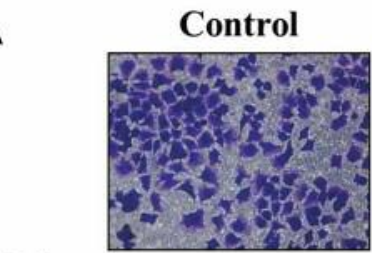

$48 \mathrm{~h}$

Control

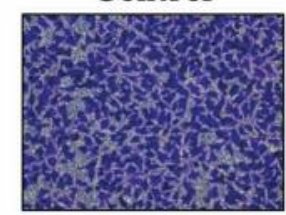

1

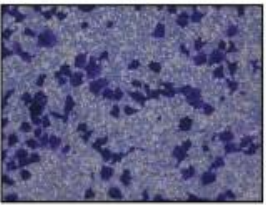

0.5

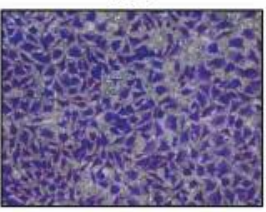

2

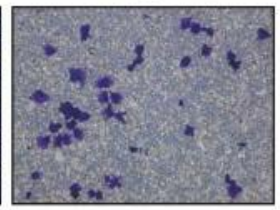

1

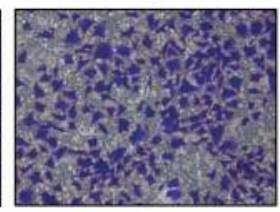

$2.5 \quad(\mu \mathrm{M})$

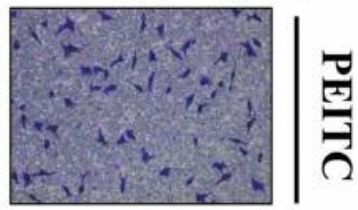

$2 \quad(\mu \mathrm{M})$
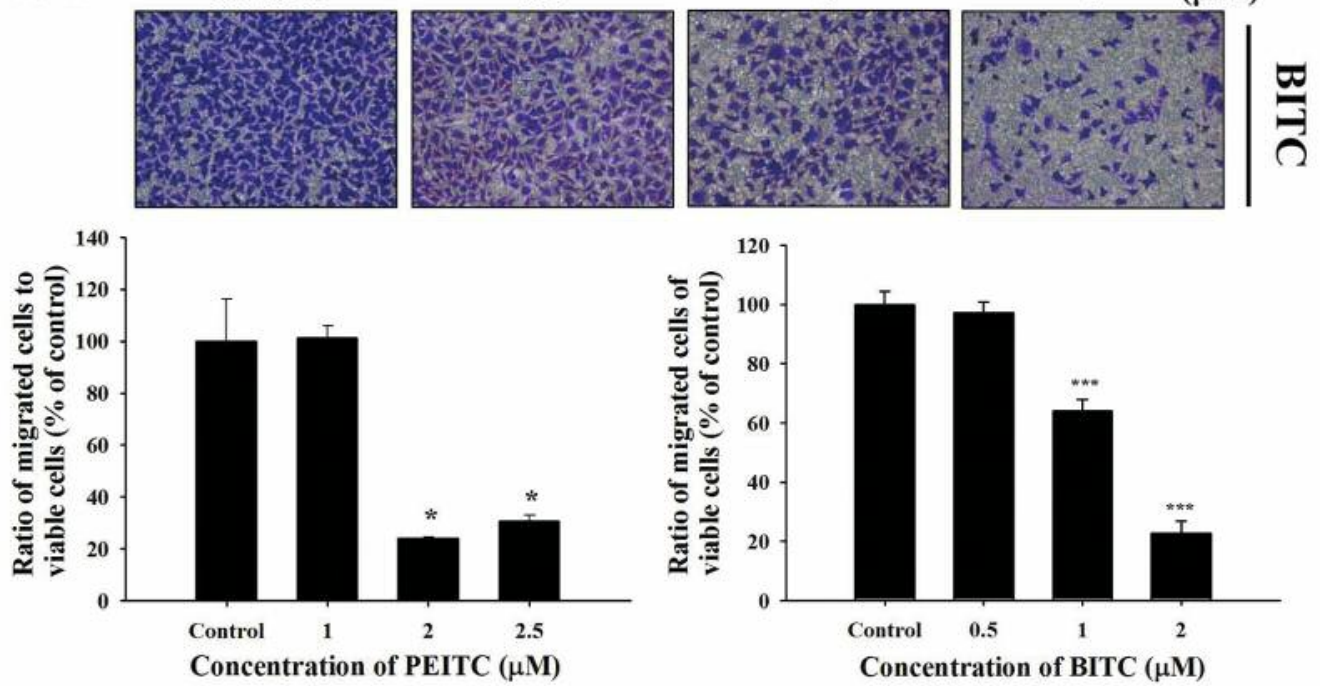

B

Control

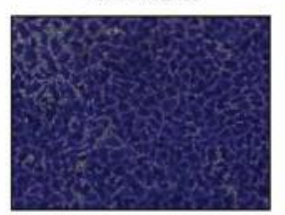

1

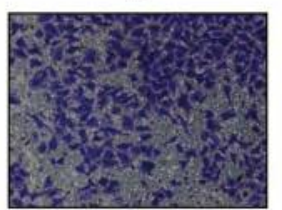

0.5

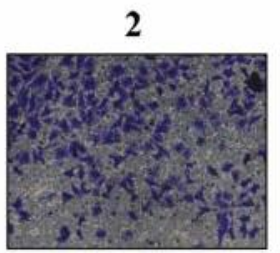

1
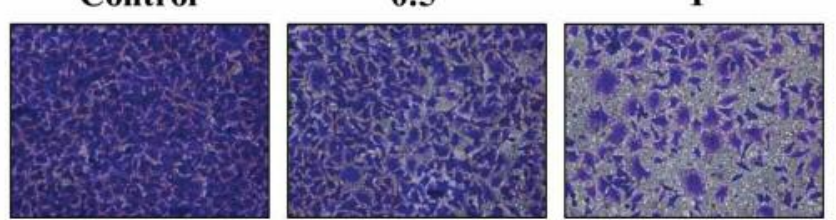

$2.5(\mu \mathrm{M})$

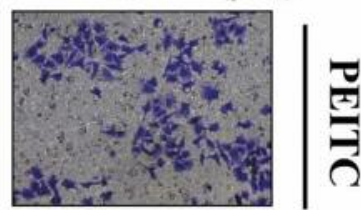

$2 \quad(\mu \mathrm{M})$
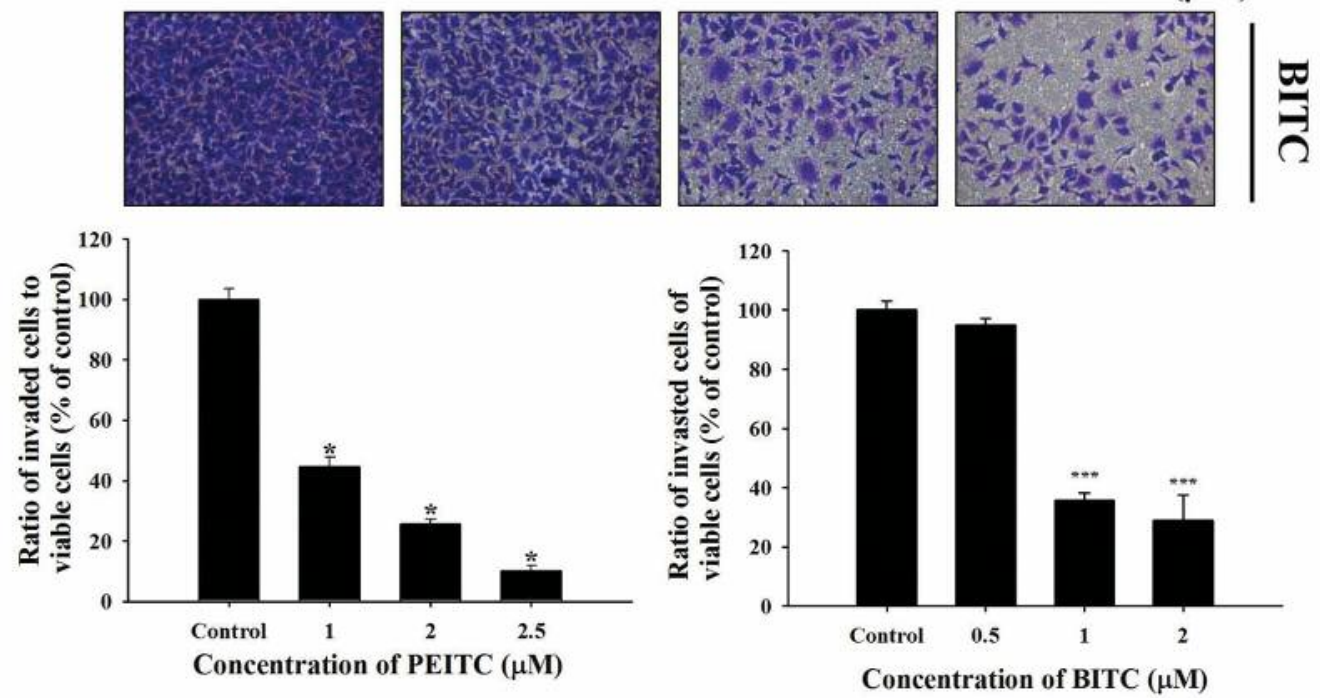

Figure 3. PEITC and BITC suppressed cell migration and invasion of A375.S2 cells in vitro. Cells $\left(5 \times 10^{4}\right.$ cells/well) were placed on filter (coated with collagen for migration or matrigel for invasion) and were treated with PEITC $(0,1,2$ and $2.5 \mu \mathrm{M})$ or BITC $(0,0.5,1$ and $2 \mu \mathrm{M})$ for $48 \mathrm{~h}$. A375.S2 cells penetrated through to the lower surface of the filter and were stained with crystal violet and photographed under a light microscope at $\times 200$ (A and B) and cells were counted, as described in Materials and Method. Results were obtained from three independent experiments. $* p<0.05$ and $* * * p<0.001$, significant difference between PEITC- or BITC-treated groups and the control, as analyzed by the Student's t-test. 


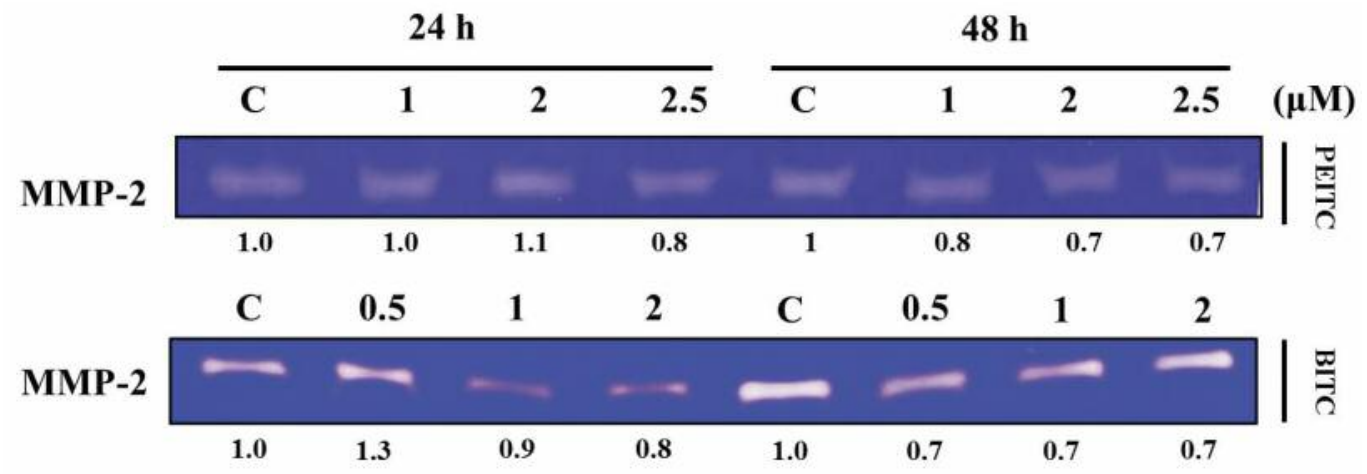

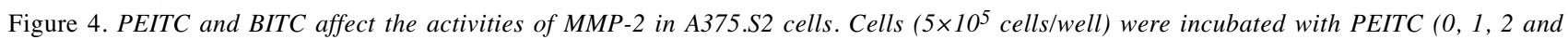
$2.5 \mu \mathrm{M})$ or BITC $(0,0.5,1$ and $2 \mu \mathrm{M})$ for 24 and $48 \mathrm{~h}$ and then conditioned media were harvested for gelatin zymography assay, as described in Materials and Methods.

Electrophoretic mobility shift assay (EMSA). After treatment, cells were collected and nuclear extracts were prepared by the NE-PER Nuclear and Cytoplasmic Extraction kit (Pierce, Rockford, Illinois, USA). $5 \mu$ g nuclear extract proteins were used to perform EMSA with a LightShift Chemiluminescent EMSA Kit (Pierce, Rockford, Illinois, USA) according to the protocol of the manufacturer as described previously (33).

Statistical analysis. Results are presented as mean \pm SD. A significant difference between the PEITC and BITC-treated and control groups were compared by Student's $t$-test. A $p<0.05$ was considered as an indication of statistical significance.

\section{Results}

PEITC and BITC decrease viability of A375.S2 cells. As indicated in Figure 1, PEITC $(1-5 \mu \mathrm{M})$ and BITC $(0.5-8 \mu \mathrm{M})$ treatment for $48 \mathrm{~h}$ exhibited a strong cytotoxic activity in A375.S2 cells in vitro. Therefore, we selected 1,2.5 and $5 \mu \mathrm{M}$ of PEITC and $0.5,1$ and $2 \mu \mathrm{M}$ of BITC concentrations for scratch wound healing assay, cell migration and invasion, western blotting and EMSA experiments.

PEITC and BITC inhibited cell mobility of A375.S2 cells. As indicated in Figure 2 which was obtained from wound healing assay, $24 \mathrm{~h}$ treatment of A375.S2 cells with PEITC and BITC inhibited the closure rate of the scratch, compared to the control group. The effect of PEITC was dose dependent but that of BITC was not (Figure 2).

PEITC and BITC inhibited cell migration and invasion of A375.S2 cells. To study migration and invasion, transwell chambers coated with collagen or matrigel were used, respectively, and the results are shown in Figure 3. Figure $3 \mathrm{~A}$ indicates that PEITC ( 2 and $2.5 \mu \mathrm{M})$ and BITC (1 and 2 $\mu \mathrm{M})$ significantly inhibited the migration of A375.S2 cells. PEITC inhibited cell invasion of A375.S2 cells in dose- dependent manner but BITC at 1 and $2 \mu \mathrm{M}$ significantly inhibited the invasion of A375.S2 cells (Figure 3B).

PEITC and BITC inhibited MMP-2 activities in A375.S2 cells. After A375.S2 cells were treated with various concentrations of PEITC and BITC for 24 or $48 \mathrm{~h}$, culture medium were harvested to assay MMP-2 activities by using gelatin zymography and the results are shown in Figure 4. Results indicate that following $24 \mathrm{~h}$ treatment, only $2.5 \mu \mathrm{M}$ of PEITC inhibited MMP-2 activity. However, following $48 \mathrm{~h}$ treatment, 1, 2 and $2.5 \mu \mathrm{M}$ of PEITC inhibited MMP-2 activity. 1 and $2 \mu \mathrm{M}$ of BITC treatment for $24 \mathrm{~h}$ inhibited MMP-2 activity. 0.5-2 $\mu \mathrm{M}$ treatment for $48 \mathrm{~h}$ with BITC inhibited MMP-2 activity.

PEITC and BITC affect key metastasis-related proteins in A375.S2 cells. In order to understand whether PEITC and BITC inhibited A375.S2 cell migration and invasion through inhibition of metastasis associated protein expression, cells were treated with PEITC $(0,1,2$ and $2.5 \mu \mathrm{M})$ and BITC $(0,0.5,1$ and $2 \mu \mathrm{M}$ ) for 24 or $48 \mathrm{~h}$ and cell extracts were harvested for Western blotting. The results revealed that MAPK associated signaling proteins such as p-p38, p-JNK1/2 and p-ERK1/2 are involved. The levels of p-p38 were decreased at PEITC $(2.5 \mu \mathrm{M})$ and BITC $(2 \mu \mathrm{M})$ at both time treatments (Figure 5A). PEITC $(1-2.5 \mu \mathrm{M})$ and BITC $(0.5-2 \mu \mathrm{M})$ decreased the levels of $\mathrm{p}$ JNK1/2 proteins at $48 \mathrm{~h}$ treatment (Figure 5A). PEITC (2.5 $\mu \mathrm{M}$ ) reduced $\mathrm{p}$-ERK $1 / 2$ proteins at $48 \mathrm{~h}$ treatment (Figure 5A). However, BITC $(0.5-2 \mu \mathrm{M})$ treatment at 24 and $48 \mathrm{~h}$ increased p-ERK1/2 levels (Figure 5A).

PEITC (1-2.5 $\mu \mathrm{M})$ inhibited PKC and PI3K proteins at 24 and $48 \mathrm{~h}$ treatment (Figure 5B), however, BITC $(2 \mu \mathrm{M})$ treatment decreased PKC and BITC $(0.2-5 \mu \mathrm{M})$ treatment increased PI3K levels at 24 and $48 \mathrm{~h}$ (Figure 5B). PEITC (1$2.5 \mu \mathrm{M})$ increased p-AKT (Ser473) levels at $24 \mathrm{~h}$ treatment 
A

PEITC

BITC

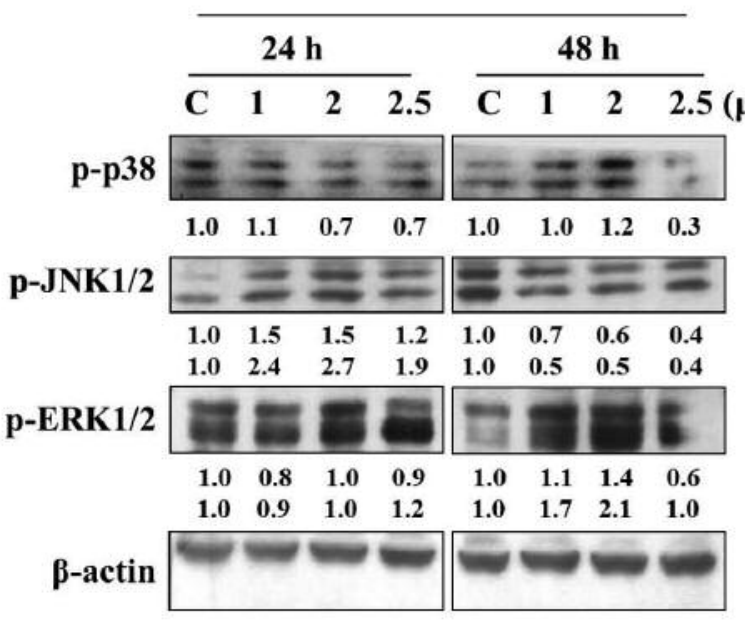

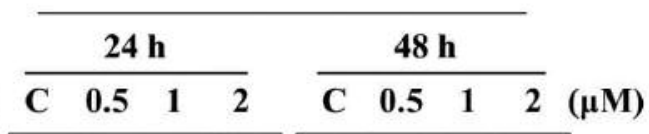

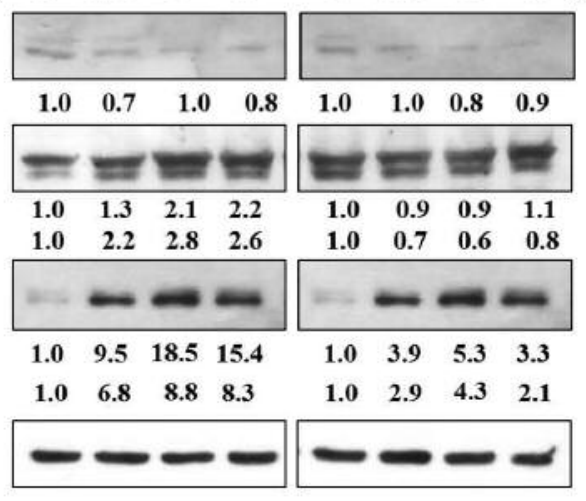

B

PEITC

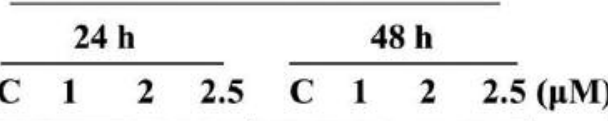

PKC
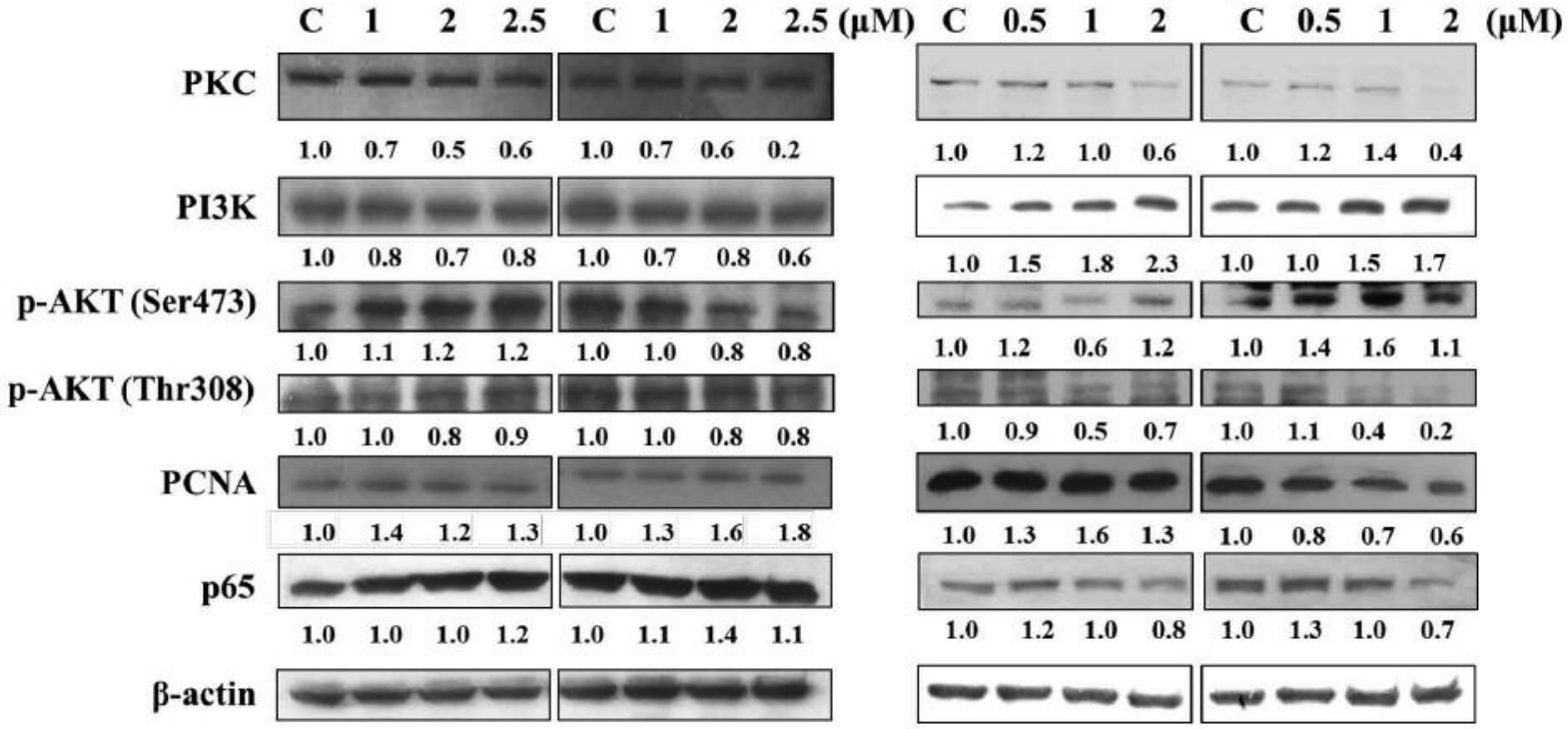

C

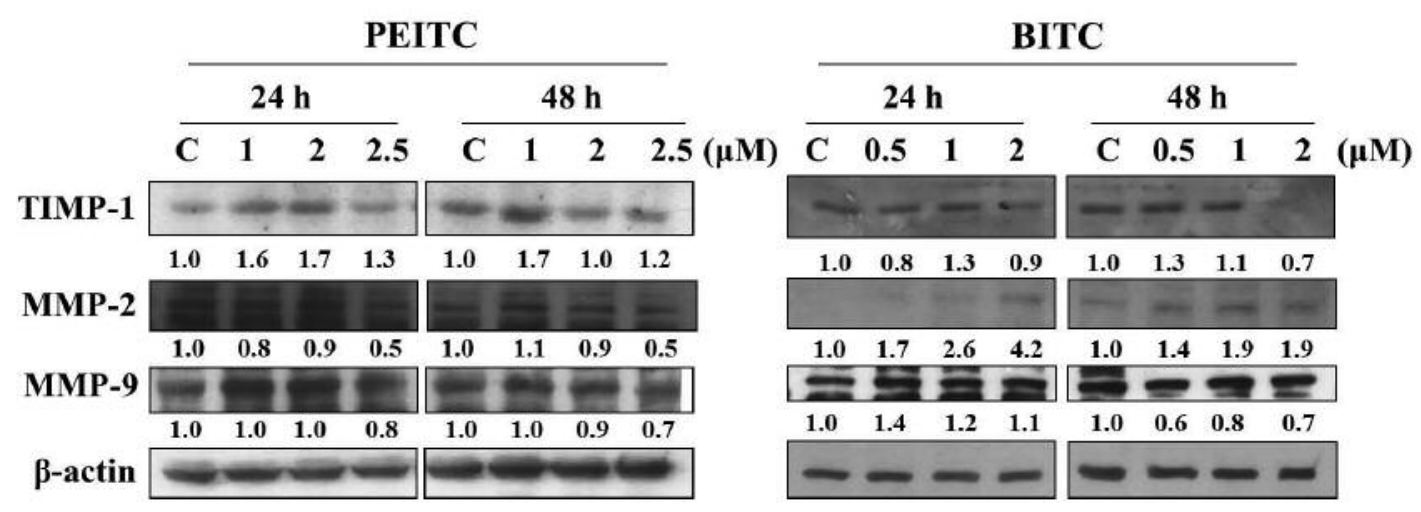


D

PEITC

BITC

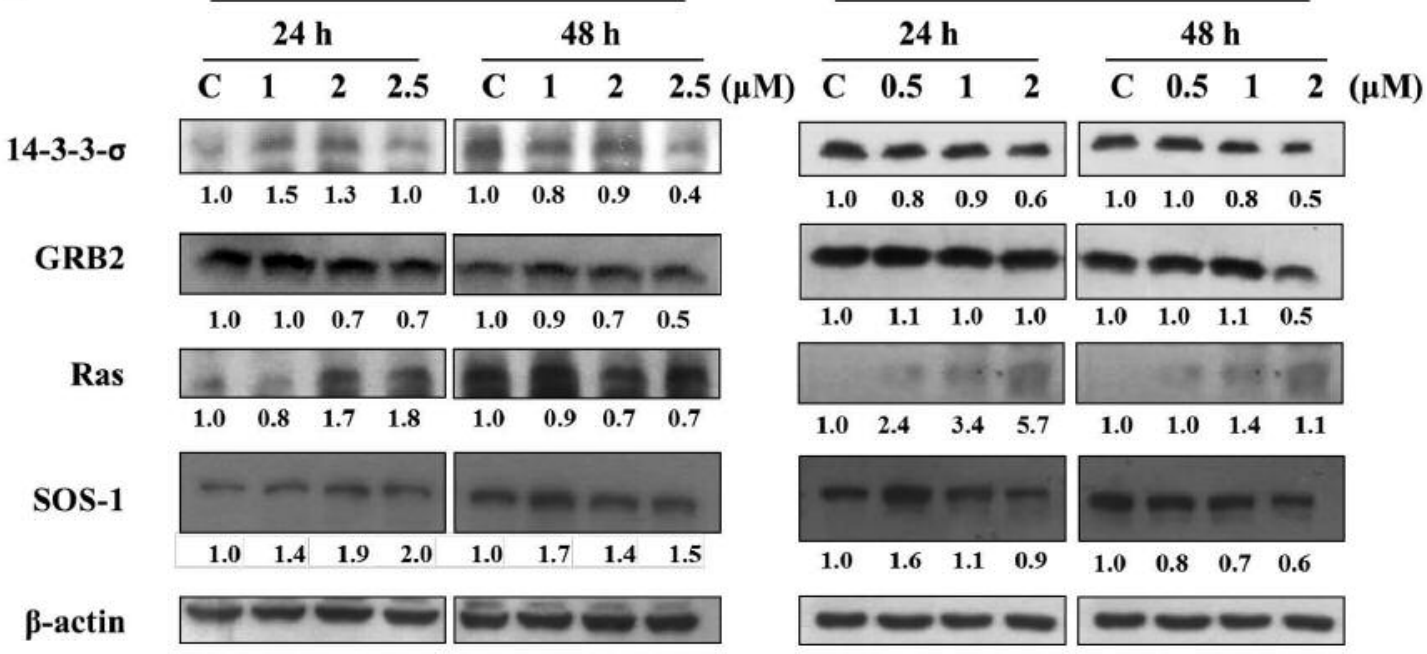

E

PEITC

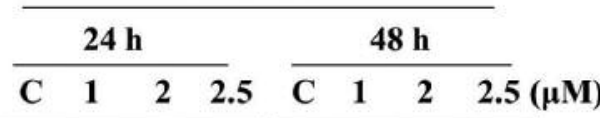

BITC

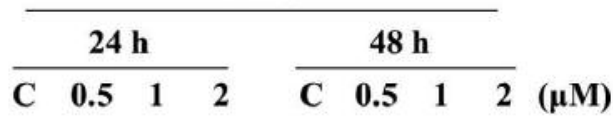
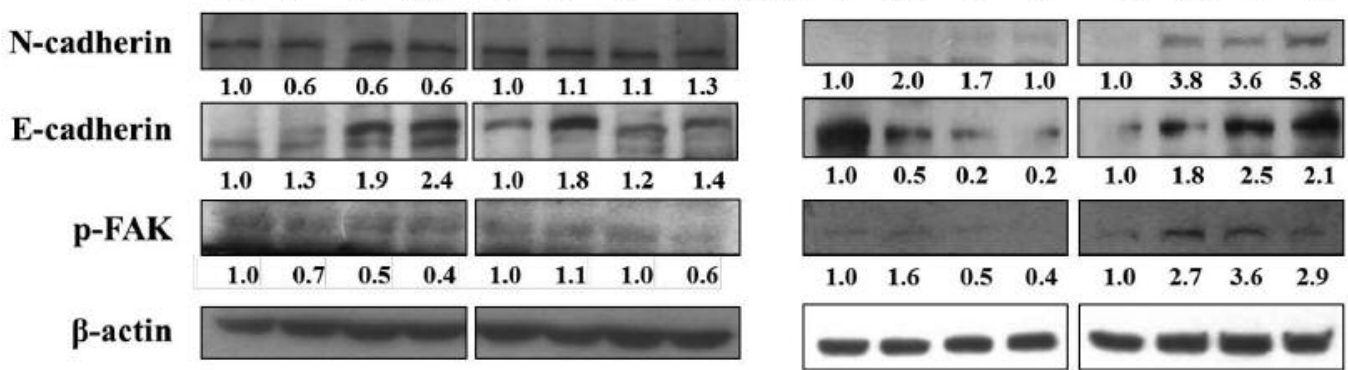

Figure 5. PEITC and BITC affect the levels of associated proteins in migration and invasion of A375.S2 cells. Cells (1.5 $\times 10^{6}$ cells/dish) were treated with PEITC $(0,1,2$ and $2.5 \mu \mathrm{M})$ and BITC $(0,0.5,1$ and $2 \mu \mathrm{M})$ for 24 and $48 \mathrm{~h}$. Cells were collected and total protein was determined for SDSPAGE gel electrophoresis, as described in Materials and Methods. The levels of p-p38, p-ERK1/2 and p-JNK1/2 (A); PKC, PI3K, p-AKT(Ser473),

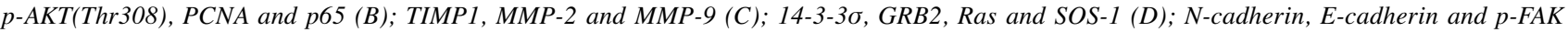
(E) were estimated by western blotting.

but decreased them at $48 \mathrm{~h}$ (Figure 5B). BITC $(2 \mu \mathrm{M})$ treatment at both time periods increased p-AKT (Ser473) levels (Figure 5B). PEITC and BITC treatment at both time periods decreased p-AKT (Thr308) (Figure 5B). PEITC (1$2.5 \mu \mathrm{M})$ increased PCNA and $\mathrm{p} 65$ at 24 and $48 \mathrm{~h}$ treatment. BITC only at $24 \mathrm{~h}$ treatment increased PCNA, but decreased PCNA levels at $48 \mathrm{~h}$ treatment (Figure 5B) and decreased p65 at $2 \mu \mathrm{M}$ at both time periods (Figure $5 \mathrm{~B}$ ).

PEITC (1-2.5 $\mu \mathrm{M})$ increased TIMP-1 at 24 and $48 \mathrm{~h}$ treatment, but $2 \mu \mathrm{M}$ BITC treatment at 24 and $48 \mathrm{~h}$ decreased TIMP-1 (Figure 5C). PEITC (1-2.5 $\mu \mathrm{M})$ decreased MMP-2 at 24 and $48 \mathrm{~h}$ treatment but BITC $(0.5-2 \mu \mathrm{M})$ treatment at 24 and $48 \mathrm{~h}$ increased MMP-2 (Figure 5C).
PEITC $(2.5 \mu \mathrm{M})$ decreased MMP-9 at 24 and $48 \mathrm{~h}$ treatment but BITC $(0.5-2 \mu \mathrm{M})$ treatment at 24 increased MMP-9 and $48 \mathrm{~h}$ treatment decreased MMP-9 (Figure 5C).

PEITC (1-2.5 $\mu \mathrm{M})$ decreased $14-3-3 \sigma$ only at $48 \mathrm{~h}$ treatment but BITC $(0.5-2 \mu \mathrm{M})$ decreased 14-3-3 $\sigma$ at both 24 and $48 \mathrm{~h}$ (Figure 5D). PEITC (1-2.5 $\mu \mathrm{M})$ decreased GRB2 at 24 and $48 \mathrm{~h}$ treatment but BITC $(2 \mu \mathrm{M})$ only at $48 \mathrm{~h}$ decreased GRB2 (Figure 5D). PEITC $(2-2.5 \mu \mathrm{M})$ increased Ras levels at $24 \mathrm{~h}$ and decreased them at $48 \mathrm{~h}$, but BITC (0.5$2 \mu \mathrm{M}$ ) increased Ras at both time periods (Figure 5D). PEITC (1-2.5 $\mu \mathrm{M})$ increased SOS-1 for both time periods, but BITC only at 0.5 and $1 \mu \mathrm{M}$ increased SOS- 1 at $24 \mathrm{~h}$ and decreased of all doses at $48 \mathrm{~h}$ (Figure 5D). 
PEITC (1-2.5 $\mu \mathrm{M})$ decreased levels of N-cadherin at $24 \mathrm{~h}$ but increased them at $48 \mathrm{~h}$ (Figure 5E). BITC (0.1-2 $\mu \mathrm{M})$ increased $\mathrm{N}$-cadherin at both time periods (Figure $5 \mathrm{E}$ ). PEITC (1-2.5 $\mu \mathrm{M})$ increased E-cadherin at 24 and $48 \mathrm{~h}$, however, BITC $(0.5-2 \mu \mathrm{M})$ at $24 \mathrm{~h}$ decreased and at $48 \mathrm{~h}$ increased levels of E-cadherin (Figure 5E). PEITC (1-2.5 $\mu \mathrm{M}$ ) decreased p-FAK at $24 \mathrm{~h}$ but at $48 \mathrm{~h}$ treatment only at $2.5 \mu \mathrm{M}$ decrease p-FAK levels (Figure $5 \mathrm{E}$ ). $0.5 \mu \mathrm{M}$ of BITC at $24 \mathrm{~h}$ and $0.5-2 \mu \mathrm{M}$ of BITC at $48 \mathrm{~h}$ increased p-FAK, respectively (Figure 5E).

PEITC and BITC affected the binding of NF- $\mathrm{kB}$ p65 to DNA in A375.S2 cells. For further investigating whether or not PEITC and BITC affect NF- $\mathrm{kB}$ expression and the binding of NF-kB p65 to DNA in A375.S2 cells, cells were treated with PEITC $(0,1,2.5$ and $5 \mu \mathrm{M})$ and $\operatorname{BITC}(0,0.5,1$ and $2.5 \mu \mathrm{M})$ for $48 \mathrm{~h}$ and were collected for Western blotting and EMSA assay. The results are shown in Figure 6. The levels of nuclear NF-kB protein were increased at (1-2.5 $\mu \mathrm{M})$ treatment with PEITC but BITC treatment at all doses decreased NF-kB expression (Figure 6). Furthermore, NF$\mathrm{kB}$ p65 bind to DNA was decreased following PEITC treatment at $2.5 \mu \mathrm{M}$ but $1-2 \mu \mathrm{M}$ treatment increased binding; however, BITC treatment at 0.5-2 $\mu \mathrm{M}$ decreased binding of NF-kB to DNA in A375.S2 cells (Figure 6).

\section{Discussion}

Although there reports indicating that about $90 \%$ of cancer deaths are via cancer cell metastasis, so far, there is no complete understanding regarding the exact pathogenetic mechanisms involved in metastasis (34). Despite the fact that numerous studies have already demonstrated that PEITC and BITC induce apoptotic cell death in many cancer cell lines, the molecular mechanisms by which PEITC and BITC affect cell migration and invasion in human melanoma A375.S2 cells are unclear. Herein, we investigated the effect of PEITC and BITC on migration and invasion in A375.S2 cells. Results indicated that PEITC and BITC display cytotoxic effects on A375.S2 cells in a dose depedent manner (Figure 1) $(1,2.5$ and $5 \mu \mathrm{M}$ of PEITC and $0.5,1$ and $2 \mu \mathrm{M}$ of BITC). PEITC displayed a dose-dependent inhibition of mobility of A375.S2 cells (Figure 2), however, BITC did not (Figure 2). PEITC and BITC have significantly suppressed the migration of A375.S2 cells (Figure 3A) and inhibited cell invasion of A375.S2 cells in a dose-dependent manner (Figure 3B). PEITC and BITC at examined doses significantly inhibited MMP-2 activity in A375.S2 cells (Figure 4). PEITC and BITC have affected MAPK signaling associated proteins such as p-ERK1/2, p-p38 and p-JNK1/2 (Figure 5A). The PEITC (1-2.5 $\mu \mathrm{M}$ ) decreased PKC and PI3K (Figure 5B) but BITC decreased PKC only at $2 \mu \mathrm{M}$ and both time treatments led to increased PI3K (Figure 5B) in A375.S2 cells. PEITC increased PCNA at 24 and $48 \mathrm{~h}$ treatment but BITC only increased at $24 \mathrm{~h}$ treatment and decreased at $48 \mathrm{~h}$ (Figure 5B). PEITC reduced MMP-2 protein levels but BITC increased them. Thus, our findings indicate that PEITC and BITC have anti-metastatic activity in melanoma.

We used wound healing assay and transwell chamber coated with collagen or matrigel to assay for cell migration and invasion. Results indicate that PEITC and BITC suppressed cell mobility, migration and invasion of A375.S2 cells at non-cytotoxic concentrations (Figures 2 and 3). Both assays are well known for measuring cell migration and invasion in vitro $(20,22,23)$. We also used gelatin zymography assay for measuring MMP-2 activity in A375.S2 cells after exposure to PEITC and BITC. Numerous studies have used gelatin zymography assay for measuring MMP-2 activity in cancer cells in vitro $(20,22,23)$. It is well-documented that MMPs play an important role in degrading the extracellular matrix (ECM) which could be a mechanical barrier to cell movement. Furthermore, the proteolytic activities of MMPs have been shown to be involved in the process of metastasis including cell adhesion, migration and invasion (35-38). Therefore, the inhibition of MMPs has been recognized to lead in suppression of cancer cell metastasis $(28,29)$ and MMPs have been shown to be present in melanoma (39) and many cancer cells express high levels of MMPs that facilitate cancer invasion and metastasis (40). We evaluated MMP-2 and MMP-9 activities and the levels of both proteins which are associated with reduced survival in human malignancies $(41,42)$ and with metastatic cancer and tumor-induced angiogenesis (43).

We found that PEITC inhibited MMP-2 activities (Figure 4) and secretion (Figure 5C) as assayed by gelatin zymography and western blotting, respectively. However, BITC inhibited MMP-2 activity but increased MMP-2 protein levels at all examined doses following 24 or $48 \mathrm{~h}$ treatment. It has been reported that MMP-2 is associated with tumor invasion and angiogenesis and that inhibited MMP-2 could suppress tumor metastasis $(44,45)$.

It is well-documented that mitogen-activated protein kinase (MAPK) (p38, ERK1/2 and JNK1/2) pathway is involved cell death and survival $(46,47)$ and is also involved in the regulation of the expression of MMP-2 and MMP-9 (48). Herein, we found that PEITC $(2.5 \mu \mathrm{M})$ and BITC $(2 \mu \mathrm{M})$ decreased the levels of p-p38 at both time treatments. PEITC (1-2.5 $\mu \mathrm{M})$ significantly inhibited $\mathrm{p}-\mathrm{JNK} 1 / 2$ proteins at $48 \mathrm{~h}$ treatment but BITC treatment increased $\mathrm{p}-\mathrm{JNK} 1 / 2$ levels at $24 \mathrm{~h}$ treatment (Figure 5A). PEITC $(2.5 \mu \mathrm{M})$ inhibited p-ERK $1 / 2$ proteins at $48 \mathrm{~h}$ treatment (Figure $5 \mathrm{~A}$ ) but BITC $(0.5-2 \mu \mathrm{M})$ treatment at 24 and $48 \mathrm{~h}$ increased pERK1/2 levels (Figure 5A). Thus, PEITC and BITC may affect cell migration and invasion of A375.S2 cells via MAPK pathway. MAPK pathway regulated cellular invasion and metastasis (49) and suppression of MAPK pathway 

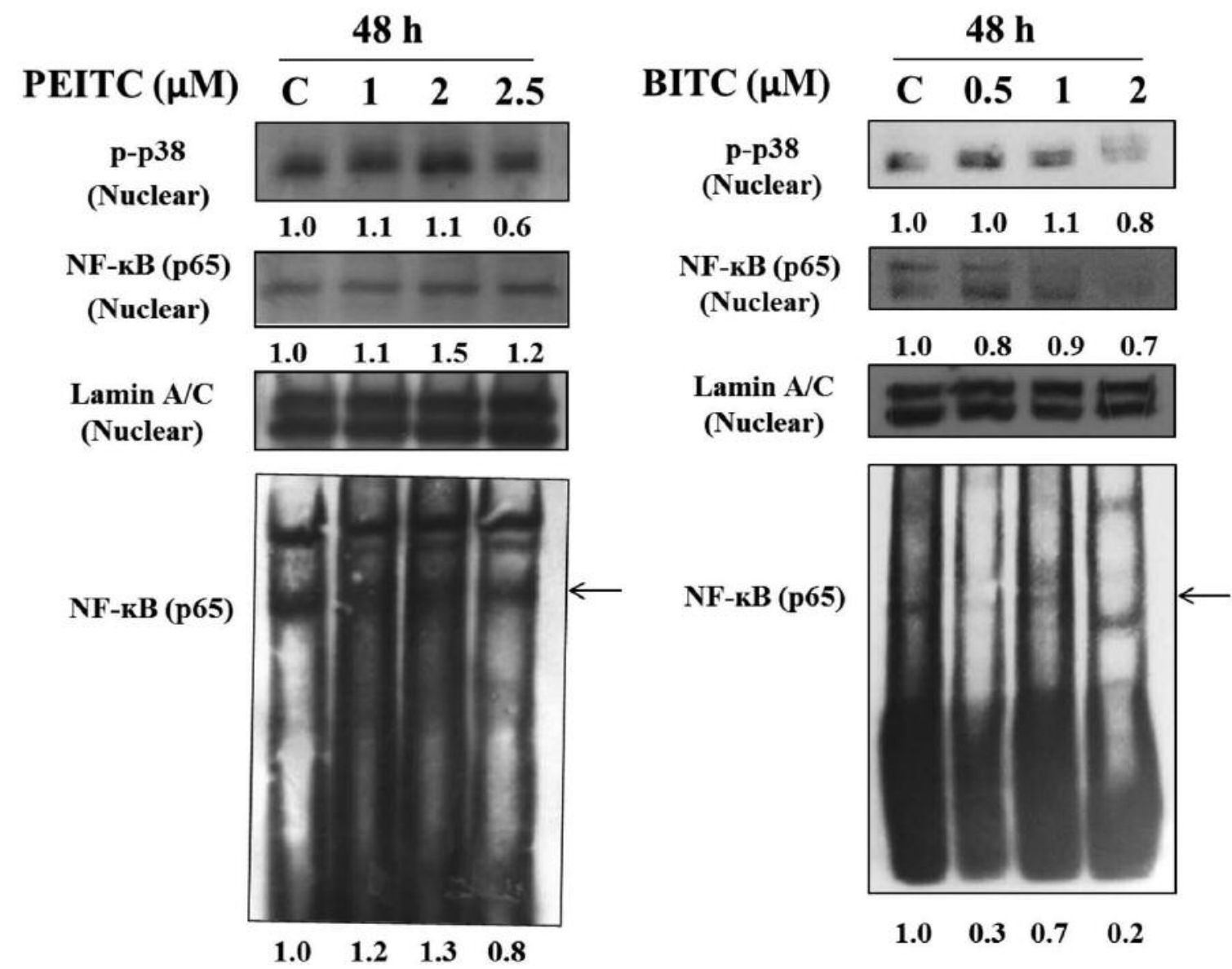

Figure 6. PEITC and BITC affect the binding of NF-kB p65 on DNA in A375.S2 cells. Cells were treated with PEITC (0, 1, 2 and $2.5 \mu$ MM) and BITC $(0,0.5,1$ and $2 \mu M)$ for $48 \mathrm{~h}$ and then were assayed using western blotting and EMSA, as described in Materials and Methods.

could prevent cancer's invasion and metastasis including in melanoma $(50,51)$.

We found that PEITC inhibited PKC and PI3K proteins (Figure 5B) and BITC decreased PKC only at $2 \mu \mathrm{M}$ and increased PI3K levels at 24 and $48 \mathrm{~h}$ (Figure 5B). PEITC (1$2.5 \mu \mathrm{M})$ increased $\mathrm{p}$-AKT $(\mathrm{Ser} 473)$ at $24 \mathrm{~h}$ treatment but decreased them at $48 \mathrm{~h}$ (Figure 5B). BITC $(2 \mu \mathrm{M})$ increased p-AKT (Ser473) levels (Figure 5B). PEITC and BITC treatment at both time periods led to decreased p-AKT (Thr308) (Figure 5B). It has been reported that AKT activation could induce cancer invasion and metastasis by stimulating secretion of MMPs (52, 53). Furthermore, activated $\mathrm{PI} 3 \mathrm{~K} / \mathrm{AKT}$ signaling is involved in tumor cell invasion and oncogenesis $(54,55)$ and it is also involved melanoma cells invasion (56), however, the inhibition of the $\mathrm{PI} 3 \mathrm{~K} / \mathrm{AKT}$ pathway led to decreased invasion of melanoma cells $(52,53)$. PEITC $(1-2.5 \mu \mathrm{M})$ increased E-cadherin at 24 and $48 \mathrm{~h}$ treatment, but BITC $(0.5-2 \mu \mathrm{M})$ treatment decreased E-cadherin at $24 \mathrm{~h}$ but increased at $48 \mathrm{~h}$ (Figure
5E). AKT and PI3K have been reported to suppress transcription of the E-cadherin gene (57).

NF-kB has been shown to be linked to tumor cell proliferation, survival, invasion, and metastasis (58) and chemo- and radio-resistance $(59,60)$. Herein, we found that PEITC increased the levels of nuclear NF-kB protein but BITC decreased NF-kB expression (Figure 6). We also used EMSA assay to show that PEITC $(1-2 \mu \mathrm{M})$ promoted DNA bindings but BITC $(0.5-2 \mu \mathrm{M})$ inhibited DNA binding of NF-KB in A375.S2 cells (Figure 6). BITC reduction of binding of NF-kB was accompanied by inhibition of the nuclear protein expression of this factor in A375.S2 cells. From the cytoplasm NF-kB translocates to the nucleus for binding on the promoter region of $M M P-9$ gene to elevate gene expression $(58,61)$.

Taken together, our results indicate that PEITC and BITC significantly inhibit cell mobility, migration and invasion of A375.S2 cells in vitro. Western blotting assays also indicated that PEITC and BITC inhibited expression of metastasis 
associated protein such as MAPKs, MMP-2, MMP-9, Ecadherin and NF-kB in A375.S2 cells. NF-kB translocates to nuclei for binding to promoter of target gens. These findings suggest that both PEITC and BITC can be considered to be co- chemotherapeutic treatments for melanoma cells in the future.

\section{Conflicts of Interest}

The Authors do not have any conflicts of interest to disclose.

\section{Acknowledgements}

This work was supported by the China Medical University, Taichung, Taiwan [grant numbers CMU106-ASIA-01]. This work was supported by the National Science Council, Taipei, Taiwan [grant numbers NSC103-2320-B-039-037-].

\section{References}

1 Vyas R, Thompson CL, Zargar H, Selph J and Gerstenblith MR: Epidemiology of genitourinary melanoma in the United States: 1992 through 2012. J Am Acad Dermatol 75: 144-150, 2016.

2 Siegel RL, Miller KD and Jemal A: Cancer Statistics, 2017. CA Cancer J Clin 67: 7-30, 2017.

3 Sykes EK, Mactier S and Christopherson RI: Melanoma and the unfolded protein response. Cancers (Basel) 8: 30, 2016.

4 Geller AC, Swetter SM, Brooks K, Demierre MF and Yaroch AL: Screening, early detection, and trends for melanoma: current status (2000-2006) and future directions. J Am Acad Dermatol 57: 555-572, 2007.

5 Sabel MS, Kozminski D, Griffith K, Chang AE, Johnson TM and Wong S: Sentinel lymph node biopsy use among melanoma patients 75 years of age and older. Ann Surg Oncol 22: 2112$2119,2015$.

6 Hamm C, Verma S, Petrella T, Bak K and Charette M: Biochemotherapy for the treatment of metastatic malignant melanoma: a systematic review. Cancer Treat Rev 34: 145-156, 2008.

7 Miyoshi N, Watanabe E, Osawa T, Okuhira M, Murata Y, Ohshima $\mathrm{H}$ and Nakamura Y: ATP depletion alters the mode of cell death induced by benzyl isothiocyanate. Biochim Biophys Acta 1782: 566-573, 2008.

8 Yan H, Zhu Y, Liu B, Wu H, Li Y, Wu X, Zhou Q and Xu K: Mitogen-activated protein kinase mediates the apoptosis of highly metastatic human non-small cell lung cancer cells induced by isothiocyanates. Br J Nutr 106: 1779-1791, 2011.

9 Liu KC, Huang YT, Wu PP, Ji BC, Yang JS, Yang JL, Chiu TH, Chueh FS and Chung JG: The roles of AIF and Endo G in the apoptotic effects of benzyl isothiocyanate on DU 145 human prostate cancer cells via the mitochondrial signaling pathway. Int J Oncol 38: 787-796, 2011.

10 Tang K, Lin Y and Li LM: The role of phenethyl isothiocyanate on bladder cancer ADM resistance reversal and its molecular mechanism. Anat Rec (Hoboken) 296: 899-906, 2013.

11 Sehrawat A, Croix CS, Baty CJ, Watkins S, Tailor D, Singh RP and Singh SV: Inhibition of mitochondrial fusion is an early and critical event in breast cancer cell apoptosis by dietary chemopreventative benzyl isothiocyanate. Mitochondrion 30: 67-77, 2016.
12 Batra S, Sahu RP, Kandala PK and Srivastava SK: Benzyl isothiocyanate-mediated inhibition of histone deacetylase leads to NF-kappaB turnoff in human pancreatic carcinoma cells. Mol Cancer Ther 9: 1596-1608, 2010.

13 Huang SH, Wu LW, Huang AC, Yu CC, Lien JC, Huang YP, Yang JS, Yang JH, Hsiao YP, Wood WG, Yu CS and Chung JG: Benzyl isothiocyanate (BITC) induces $\mathrm{G}_{2} / \mathrm{M}$ phase arrest and apoptosis in human melanoma A375.S2 cells through reactive oxygen species (ROS) and both mitochondria-dependent and death receptor-mediated multiple signaling pathways. J Agric Food Chem 60: 665-675, 2012.

$14 \mathrm{Xu}$ C, Shen G, Chen C, Gelinas C and Kong AN: Suppression of NF-kappaB and NF-kappaB-regulated gene expression by sulforaphane and PEITC through IkappaBalpha, IKK pathway in human prostate cancer PC-3 cells. Oncogene 24: 4486-4495, 2005.

15 Bommareddy A, Hahm ER, Xiao D, Powolny AA, Fisher AL, Jiang Y and Singh SV: Atg5 regulates phenethyl isothiocyanateinduced autophagic and apoptotic cell death in human prostate cancer cells. Cancer Res 69: 3704-3712, 2009.

16 Chou YC, Chang MY, Wang MJ, Liu HC, Chang SJ, Harnod T, Hung $\mathrm{CH}$, Lee HT, Shen $\mathrm{CC}$ and Chung JG: Phenethyl isothiocyanate alters the gene expression and the levels of protein associated with cell cycle regulation in human glioblastoma GBM 8401 cells. Environ Toxicol 32: 176-187, 2017.

17 Tang NY, Chueh FS, Yu CC, Liao CL, Lin JJ, Hsia TC, Wu KC, Liu HC, Lu KW and Chung JG: Benzyl isothiocyanate alters the gene expression with cell cycle regulation and cell death in human brain glioblastoma GBM 8401 cells. Oncol Rep 35: 2089-2096, 2016.

18 Yuan JM, Stepanov I, Murphy SE, Wang R, Allen S, Jensen J, Strayer L, Adams-Haduch J, Upadhyaya P, Le C, Kurzer MS, Nelson HH, Yu MC, Hatsukami D and Hecht SS: Clinical Trial of 2-Phenethyl Isothiocyanate as an Inhibitor of Metabolic Activation of a Tobacco-Specific Lung Carcinogen in Cigarette Smokers. Cancer Prev Res (Phila) 9: 396-405, 2016.

19 Lin JF, Tsai TF, Yang SC, Lin YC, Chen HE, Chou KY and Hwang TI: Benzyl isothiocyanate induces reactive oxygen species-initiated autophagy and apoptosis in human prostate cancer cells. Oncotarget 8: 20220-20234, 2017.

20 Lai KC, Hsu SC, Kuo CL, Ip SW, Yang JS, Hsu YM, Huang HY, $\mathrm{Wu}$ SH and Chung JG: Phenethyl isothiocyanate inhibited tumor migration and invasion via suppressing multiple signal transduction pathways in human colon cancer HT29 cells. J Agric Food Chem 58: 11148-11155, 2010.

21 Lai KC, Huang AC, Hsu SC, Kuo CL, Yang JS, Wu SH and Chung JG: Benzyl isothiocyanate (BITC) inhibits migration and invasion of human colon cancer HT29 cells by inhibiting matrix metalloproteinase-2/-9 and urokinase plasminogen (uPA) through PKC and MAPK signaling pathway. J Agric Food Chem 58: 2935-2942, 2010.

22 Chou YC, Chang MY, Wang MJ, Yu FS, Liu HC, Harnod T, Hung $\mathrm{CH}$, Lee HT and Chung JG: PEITC inhibits human brain glioblastoma GBM 8401 cell migration and invasion through the inhibition of uPA, Rho A, and Ras with inhibition of MMP-2, 7 and -9 gene expression. Oncol Rep 34: 2489-2496, 2015.

23 Ho CC, Lai KC, Hsu SC, Kuo CL, Ma CY, Lin ML, Yang JS and Chung JG: Benzyl isothiocyanate (BITC) inhibits migration and invasion of human gastric cancer AGS cells via suppressing ERK signal pathways. Hum Exp Toxicol 30: 296-306, 2011. 
24 Zhu M, Li W, Dong X, Chen Y, Lu Y, Lin B, Guo J and Li M: Benzyl-isothiocyanate Induces Apoptosis and Inhibits Migration and Invasion of Hepatocellular Carcinoma Cells in vitro. J Cancer 8: 240-248, 2017.

25 Ji BC, Hsiao YP, Tsai CH, Chang SJ, Hsu SC, Liu HC, Huang YP, Lien JC and Chung JG: Cantharidin impairs cell migration and invasion of A375.S2 human melanoma cells by suppressing MMP-2 and -9 through PI3K/NF-kappaB signaling pathways. Anticancer Res 35: 729-738, 2015.

26 Wu ZY, Lien JC, Huang YP, Liao CL, Lin JJ, Fan MJ, Ko YC, Hsiao YP, Lu HF and Chung JG: Casticin inhibits A375.S2 human melanoma cell migration/invasion through downregulating NF-kappaB and Matrix Metalloproteinase-2 and -1. Molecules 21: 384, 2016.

27 Huang YP and Chang NW: PPARalpha modulates gene expression profiles of mitochondrial energy metabolism in oral tumorigenesis. Biomedicine (Taipei) 6: 3, 2016.

28 Hall A: The cytoskeleton and cancer. Cancer Metastasis Rev 28: 5-14, 2009.

29 Lauffenburger DA and Horwitz AF: Cell migration: a physically integrated molecular process. Cell 84: 359-369, 1996.

30 Huang YL, Chu YL, Ho CT, Chung JG, Lai CI, Su YC, Kuo YH and Sheen LY: Antcin K, an active triterpenoid from the fruiting bodies of basswood-cultivated antrodia cinnamomea, inhibits metastasis via suppression of integrin-mediated adhesion, migration, and invasion in human hepatoma cells. J Agric Food Chem 63: 4561-4569, 2015.

31 Chan CY, Lien CH, Lee MF and Huang CY: Quercetin suppresses cellular migration and invasion in human head and neck squamous cell carcinoma (HNSCC). Biomedicine (Taipei) 6: 15, 2016.

32 Lee MR, Lin C, Lu CC, Kuo SC, Tsao JW, Juan YN, Chiu HY, Lee FY, Yang JS and Tsai FJ: YC-1 induces G0/G1 phase arrest and mitochondria-dependent apoptosis in cisplatin-resistant human oral cancer CAR cells. Biomedicine (Taipei) 7: 12, 2017.

$33 \mathrm{Wu}$ SH, Hsiao YT, Kuo CL, Yu FS, Hsu SC, Wu PP, Chen JC, Hsia TC, Liu HC, Hsu WH and Chung JG: Bufalin inhibits NCIH460 human lung cancer cell metastasis in vitro by inhibiting MAPKs, MMPs, and NF-kappaB pathways. Am J Chin Med 43: 1247-1264, 2015.

34 Steeg PS: Metastasis suppressors alter the signal transduction of cancer cells. Nat Rev Cancer 3: 55-63, 2003.

35 Morrison CJ, Butler GS, Rodriguez D and Overall CM: Matrix metalloproteinase proteomics: substrates, targets, and therapy. Curr Opin Cell Biol 21: 645-653, 2009.

36 Rodriguez D, Morrison CJ and Overall CM: Matrix metalloproteinases: what do they not do? New substrates and biological roles identified by murine models and proteomics. Biochim Biophys Acta 1803: 39-54, 2010.

37 Roy R, Yang J and Moses MA: Matrix metalloproteinases as novel biomarkers and potential therapeutic targets in human cancer. J Clin Oncol 27: 5287-5297, 2009.

38 Amar S, Smith L and Fields GB: Matrix metalloproteinase collagenolysis in health and disease. Biochim Biophys Acta, 2017. doi: 10.1016/j.bbamcr.2017.04.015. [Epub ahead of print]

39 Hofmann UB, Westphal JR, Van Muijen GN and Ruiter DJ: Matrix metalloproteinases in human melanoma. J Invest Dermatol 115: 337-344, 2000.

40 Kessenbrock K, Plaks V and Werb Z: Matrix metalloproteinases: regulators of the tumor microenvironment. Cell 141: 52-67,
2010.

41 Kallakury BV, Karikehalli S, Haholu A, Sheehan CE, Azumi N and Ross JS: Increased expression of matrix metalloproteinases 2 and 9 and tissue inhibitors of metalloproteinases 1 and 2 correlate with poor prognostic variables in renal cell carcinoma. Clin Cancer Res 7: 3113-3119, 2001.

42 Lynch CC and Matrisian LM: Matrix metalloproteinases in tumorhost cell communication. Differentiation 70: 561-573, 2002.

$43 \mathrm{Cui} \mathrm{N}, \mathrm{Hu} \mathrm{M}$ and Khalil RA: Biochemical and biological attributes of matrix metalloproteinases. Prog Mol Biol Transl Sci 147: 1-73, 2017.

44 Fan S, Liao Y, Liu C, Huang Q, Liang H, Ai B, Fu S and Zhou S: Estrogen promotes tumor metastasis via estrogen receptor beta-mediated regulation of matrix-metalloproteinase-2 in nonsmall cell lung cancer. Oncotarget, 2017. doi: 10.18632/ oncotarget.16992. [Epub ahead of print]

45 Wang Z, You D, Lu M, He Y and Yan S: Inhibitory effect of norcantharidin on melanoma tumor growth and vasculogenic mimicry by suppressing MMP-2 expression. Oncol Lett 13: 1660-1664, 2017.

46 Ma Y, Wang L, Neitzel LR, Loganathan SN, Tang N, Qin L, Crispi EE, Guo Y, Knapp S, Beauchamp RD, Lee E and Wang J: The MAPK pathway regulates intrinsic resistance to BET inhibitors in colorectal cancer. Clin Cancer Res 23: 2027-2037, 2017.

47 Moriwaki K and Asahi M: Augmented TME O-GlcNAcylation promotes tumor proliferation through the inhibition of $\mathrm{p} 38$ MAPK. Mol Cancer Res 15: 1287-1298, 2017.

48 Song G, Xu S, Zhang H, Wang Y, Xiao C, Jiang T, Wu L, Zhang T, Sun X, Zhong L, Zhou C, Wang Z, Peng Z, Chen J and Wang $\mathrm{X}$ : TIMP1 is a prognostic marker for the progression and metastasis of colon cancer through FAK-PI3K/AKT and MAPK pathway. J Exp Clin Cancer Res 35: 148, 2016.

49 Zhao J, Dong QZ, Zhong F, Cai LL, Qin ZY, Liu Y, Lin CZ, Qin LX and He FC: NMI promotes hepatocellular carcinoma progression via BDKRB2 and MAPK/ERK pathway. Oncotarget 8: 12174-12185, 2017.

50 Kee JY, Han YH, Kim DS, Mun JG, Park SH, So HS, Park SJ, Park R, Um JY and Hong SH: beta-Lapachone suppresses the lung metastasis of melanoma via the MAPK signaling pathway. PLoS One 12: e0176937, 2017.

51 Wang B, Zhang L, Zhao L, Zhou R, Ding Y, Li G and Zhao L: LASP2 suppresses colorectal cancer progression through JNK/p38 MAPK pathway meditated epithelial-mesenchymal transition. Cell Commun Signal 15: 21, 2017.

52 Lin BW, Jiao ZL, Fan JF, Peng L, Li L, Zhao ZG, Ding XY and Li HJ: Inhibitory effect of melanoma differentiation associated gene-7/interleukin-24 on invasion in vitro of human melanoma cancer cells. J Korean Med Sci 28: 833-839, 2013.

53 Shi H, Wu Y, Wang Y, Zhou M, Yan S, Chen Z, Gu D and Cai Y: Liquiritigenin potentiates the inhibitory effects of cisplatin on invasion and metastasis via downregulation MMP-2/9 and PI3 $\mathrm{K} / \mathrm{AKT}$ signaling pathway in $\mathrm{B} 16 \mathrm{~F} 10$ melanoma cells and mice model. Nutr Cancer 67: 761-770, 2015.

$54 \mathrm{Kim}$ D, Kim S, Koh H, Yoon SO, Chung AS, Cho KS and Chung J: Akt/PKB promotes cancer cell invasion via increased motility and metalloproteinase production. FASEB J 15: 19531962, 2001.

55 Shukla S, Maclennan GT, Hartman DJ, Fu P, Resnick MI and Gupta S: Activation of PI3K-Akt signaling pathway promotes prostate cancer cell invasion. Int J Cancer 121: 1424-1432, 2007. 
56 Thang ND, Yajima I, Kumasaka MY, Iida M, Suzuki T and Kato M: Deltex-3-like (DTX3L) stimulates metastasis of melanoma through FAK/PI3K/AKT but not MEK/ERK pathway. Oncotarget 6: 14290-14299, 2015.

57 Qiao M, Sheng S and Pardee AB: Metastasis and AKT activation. Cell Cycle 7: 2991-2996, 2008.

58 Perkins ND: The diverse and complex roles of NF-kappaB subunits in cancer. Nat Rev Cancer 12: 121-132, 2012.

59 Chaturvedi MM, Sung B, Yadav VR, Kannappan R and Aggarwal BB: NF-kappaB addiction and its role in cancer: 'one size does not fit all'. Oncogene 30: 1615-1630, 2011.
60 Nakanishi C and Toi M: Nuclear factor-kappaB inhibitors as sensitizers to anticancer drugs. Nat Rev Cancer 5: 297-309, 2005.

61 Vincenti MP and Brinckerhoff CE: Signal transduction and celltype specific regulation of matrix metalloproteinase gene expression: can MMPs be good for you? J Cell Physiol 213: 355-364, 2007.

Received August 23, 2017 Revised September 15, 2017 Accepted September 18, 2017 